\title{
GFIS (GEOGRAPHIC FORECASTING INFORMATION SYSTEM): A CASE STUDY IN WATER RESOURCES MANAGEMENT
}

\section{E. PAGOURTZI* \\ K. NIKOLOPOULOS \\ V. ASSIMAKOPOULOS}

School of Electrical and Computer Engineering, Forecasting Systems Unit, National Technical University of Athens.

9, Ir. Polytechniou Str., 15773 Zografou,

Athens, Greece

Selected from papers presented at the $8^{\text {th }}$ International Conference on Environmental Science and Technology,

8 - 10 September 2003, Lemnos, Greece.
*to whom all correspondence should be addressed: Tel: +30 210 772-3637, Fax: +30 210 772-3740 e-mail : ellipag@epu.ntua.gr

\begin{abstract}
The current study presents the development of a Forecasting Information System for geographic data (cross-sectional time-series for different geographic regions). GFIS, Geographic Forecasting Information System, was developed with MS Visual Basic (User Interface), ArcView (GIS) and MS Access (DBMS) during the MSc thesis of one of the authors in 2000.

GFIS is suitable for the management and forecasting for all time-series that present a geographic dimension and can be illustrated in a Geographical Information System (GIS). The forecasting capabilities of the system extend from classical time-series extrapolation methods (exponential smoothing, regression) (Assimakopoulos, 1994) to more complex methods (Theta model).

The applicability of the system was tested with a case study in Water Resources Management. GFIS was used in order to create rainfall forecasts for the watersheds in Lakonia, a region in southern Greece. The estimation, forecasting, planning and management of hydrological resources are of great importance and prerequisite for sustainable development.
\end{abstract}

KEYWORDS: Time-series, forecasting, Theta model, GIS, rainfall, hydrological resource.

\section{INTRODUCTION}

Human nature will face new millennium with many serious environmental unsolved problems that will put in great danger the survival and existence of all the species in the entire planet. As a result of development in agriculture, industry, shipping, transportation, tourism, etc, many problems created because of the uncontrollably use of natural resources and the pollution of the air, water and soils, in that degree, is beyond the ability of self - purification and defence of the ecosystem.

As long as the economic development does not adapt the principles of sustainable the pressure in the environment will increase because the production and the consuming will demand more 
natural resources than it can recreate and it will create more pollution than ever before.

The estimation, forecasting, planning and management of hydrological resources are some of the more critical requirements for the sustainable development (Ogilire, 1995; Redclift, 1993; Turner and Kerry (ed.), 1993).

The selection and processing of hydrological data plays a key role in the management and monitoring of hydrological resources (Andrieu et al., 1996). The Observed fall of level and shrinkage of resources during the last years (due to important rainfalls reduction), made imperative the need of hydrology research of watersheds (basins). This will facilitate the decision-making, which will contribute in successful phenomenon treatment (Bindlish and Barros, 2000).

Principal information on hydrologic parameters estimation could be found in various services that assemble climatic data from local meteorological stations. Data collection and processing for various hydrologic parameters calculation constitute a time-consuming work.

The proposed methodology is about data processing and storage that depend on GIS theory and forecasting methods. The methodology succeeds direct and fast data access, processing and forecasting in a GIS platform. This is the first step of the hydrological study of watersheds.

The paper' $s$ scope is to create a Geographic Forecasting Information System GFIS and to test it in the management of available hydrological data.

The case study under consideration aims at the use of GFIS in order to create rainfall forecasts for the watersheds in Lakonia, a region in southern Greece for water management.

The project was completed in three phases:

1. Implementation of geographical model that includes spatial data of region (digital elevation terrain, coast line, hydrological grid, watershed, meteorological gauges).

2. GIS topology of spatial data and appending new attributes in those data.

3. GFIS design and implementation that include data processing in GIS and forecasting rainfalls for the watersheds in Lakonia. GFIS construction involved: user interface, processing model and forecasting model.

GFIS provides an easy way to restore, append and edit hydrological data. Also defines average rain- fall in any time (hydrological year) and in any gauge (meteorological station) in research region. The most important issue is that Geographic Forecasting Information System G.F.I.S. can give excellent results that could be used in watersheds balance researches and in resource management.

\section{SYSTEM DESCRIPTION}

GFIS is suitable for the management and forecasting for all time-series that present a geographic dimension and can be illustrated in a GIS System. The forecasting capabilities of the system extend from classical time-series extrapolation methods (exponential smoothing, regression) to more complex methods (Theta model).

Main operation of GFIS is data processing and time-series forecasting. The applicability of the system was tested with a case study in Water Resources Management. GFIS was used in order to create rainfall forecasts for the watersheds in Lakonia, a region in southern Greece. The estimation, forecasting, planning and management of hydrological resources are of great importance and prerequisite for sustainable development.

The project including three phases: a) Geographical data development by digitisation, b) topology creation and data editing, and c) system and interface implementation

The G.F.I.S. developed in ARCVIEW version 3.1 and the user interface made in VISUAL BASIC 6. The database made in ACCESS.

\section{METHODOLOGY}

The methodology's philosophy in watershed simulation is:

- The basic components - objects of watersheds are points, lines and polygons that based on GIS topology.

- Attributes of those components are elevation, length, slope, soil, vegetation etc.

- Types of functions, like: infiltration, surface flow, etc.

- Linkage between objects - coverage and watershed organic parts like: running of water, hydrological grid (primary steams and sud - streams), lakes (natural - technical), swamps, nodes (points of primary and secondary streams intersection), area, canopy, elevation - slope, etc.

GFIS is an integrated system that includes sub systems, as shown in Figure 1. 


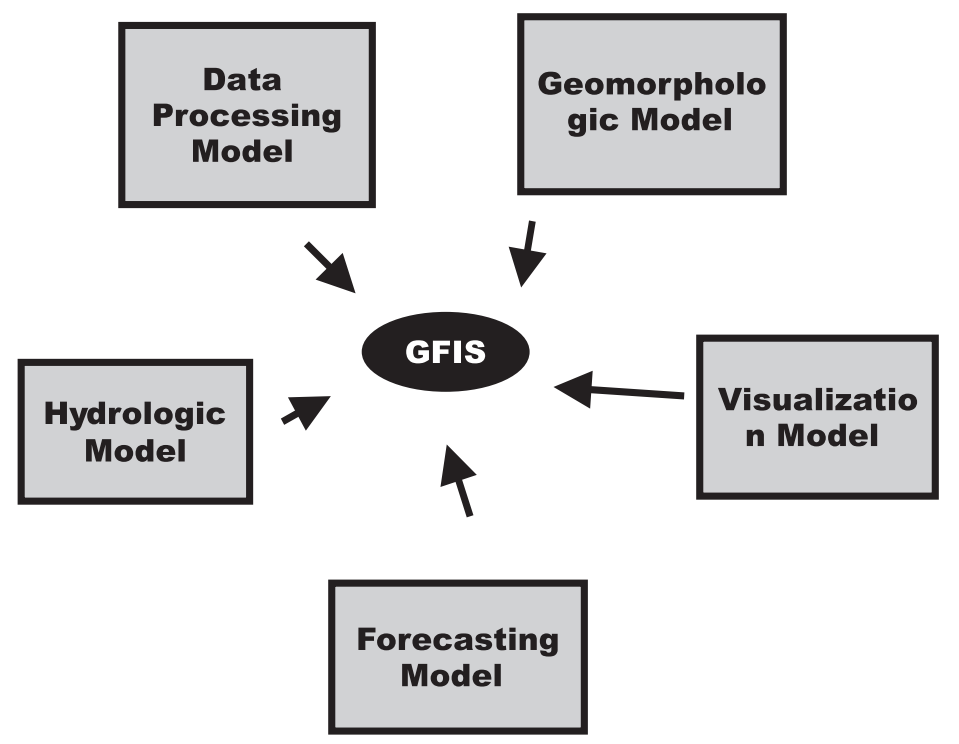

Figure 1. GFIS sub - systems

\section{FORECASTING METHODS}

GFIS forecasting capabilities extend from classical time-series extrapolation methods (exponential smoothing, regression) to more complex methods (Theta model). There is a brief presentation of forecasting methods that are used by the system.

\section{Exponential Smoothing Models}

The single exponential smoothing model is one of the common forecasting techniques used in the private sector. The model is a moving average of forecasts that have been corrected for the error observed in preceding forecasts. In the first smoothing model, there is assumed no trend or seasonal pattern.

$$
F_{t}=F_{t-1}+\alpha\left(A_{t-1}-F_{t-1}\right)
$$

where $F_{t}$ is the forecast at time $t, A_{t-\mathrm{i}}$ is the actual value at time $t-i$, and $N$ is the number of time periods averaged.

The parameter $\alpha$ is the smoothing coefficient and has an estimated value between zero and one. It is referred to as an exponential smoothing model because the value of tends to affect past values exponentially. As $\alpha$ approaches one, the forecast resembles a short-term moving average, while an $\alpha$ closer to zero tends to resemble long-term moving averages. Regardless of the value of $\alpha$, however, exponential smoothing tends to give more recent values higher implicit weights. Again, $\alpha$ is typically estimated using trial and error to secure the best fitting model, but software today can rapidly find the model that minimizes forecast error (Assimakopoulos, 1994).

\section{Simple Regression}

The simple linear regression model may be defined precisely as follows.

$$
Y_{i}=\alpha+\beta X_{i}+\varepsilon_{i}
$$

where $Y_{i}$ and $X_{i}$ represent the $i^{t h}$ observations of the variables $\mathrm{Y}$ and $\mathrm{X}$ respectively, $\alpha$ and $\beta$ are fixed (but unknown) parameters and $\varepsilon_{i}$ is a random variable that is normally distributed with mean zero and having a variance $\sigma_{\varepsilon}^{2}$.

Note the formalities in a model of this type. The expression $\alpha+\beta X_{i}$ is the regression relationship in this case a straight line - and $\alpha$ and $\beta$ are called parameters (which are unknown, but if they were known they would be fixed numbers). There are several assumptions made about $X_{i}$ and $\varepsilon_{i}$ which are important:

1. The explanatory variable $X_{i}$ takes values which are assumed to be either fixed numbers (measured without error), or they are random but uncorrelated with the error terms $\varepsilon_{i}$. In either case, the values of $X_{i}$ must not be all the same.

2. The error terms $\varepsilon_{i}$ are uncorrelated with one another. 
3. The error terms $\varepsilon_{i}$ all have mean zero and variance $\sigma_{\varepsilon}^{2}$, and have a normal distribution (Maktridakis, Wheelwright and Hyndman, 1998).

\section{The THETA model}

The model is based on the concept of modifying the local curvatures of the time series. This change is obtained from a coefficient, called Theta-coefficient (as a symbol is used the Greek letter Theta), which is applied directly to the second differences of the time series (Assimakopoulos and Nikolopoulos, 2000):

$$
\begin{gathered}
X_{\text {new }}^{\prime \prime}(\theta)=\theta X_{\text {data }}^{\prime \prime}, \\
\text { where } X_{\text {data }}^{\prime \prime}=X_{t}-2 X_{t-1}+X_{t-2}
\end{gathered}
$$

at time t.

\section{DATA}

\section{Geographical data}

For geographical model was used digitising methodology in order to create coverage of the case study region. This process included the following four steps:

- Use of maps of 1:50.000 scales. The topological maps were got in Greek Geographic Army Department.

- Topological maps was scanned and exported in files with tiff format (raster data).

- Raster data was stretched in four maps edges and transferred in Hellenic Geodetic Reference System (EGSA 87).

- Vector data creation by digitising raster data in ARCINFO.

The above-digitised data constitute the project's geographical data. Geographical data are the following:

- Contour coverage. Digitising was done with 100-meter step for high elevation areas and with 20-meter step for flat areas. In flat areas was chosen smaller digitising step, preparative to not exist large areas without information of the elevation. Null information about the elevation hinder interpolation processing for Digital Elevation Model (DEM). Contour coverage was used to develop Digital Elevation Model and Digital Elevation Model was used to develop the watersheds.

- Streams - rivers coverage. Primary and secondary streams grid was digitised. Streams coverage used for map visualization and for outfall node location. Outfall node location is very important for watershed specification.

- Coastline - inlands coverage. This coverage was digitised for map visualization reasons.

- Meteorological gauges/stations coverage. Stations coverage includes 20 meteorological gauges and used for rainfalls map visualization.

Rainfall data was gathered from the following Government's services.

- Hellenic National Meteorological Service

- Hellenic Ministry for the Environment Physical Planning and Public Works

- Hellenic Ministry of Agriculture

- Hellenic Institute of Forestal Research

\section{Hydrological data}

The hydrological data are monthly. They begin in 1952 and end in 1993. The Table 1 refers in meteorological stations information and includes name, coordinates (latitude and longitude in degrees) and elevation (in meters) of each station.

\section{RESULTS}

System includes monthly hydrological data (rainfalls) for each station (20 stations) in Lakonia region. Time series begin at 1952 and end at 1993. Forecasting Horizon is set to 10 years. System produces monthly rainfall forecasts for 1994 until 2004.

User can choose monthly data for any year from GFIS basic menu and create forecasting or show respective map layout. In table 2 selective data from system are shown.

\section{CONCLUSIONS}

Geographic Forecasts Information System has the advantage to connect and process between descriptive / qualitative attributes and their spatial position (geographical data which declare the position and the form). Each digital map is constituted by geographical data and qualitative attributes, maintaining the spatial relations between their characteristics.

G.F.I.S. main capabilities are:

- Data production from raw data and data classification in different layers

- Data use in framework of decision making

- Data management for large databases 
Table 1. Information for meteorological stations

\begin{tabular}{|c|c|c|c|c|c|}
\hline Name & Latitude & Longitude & Elevation & Time- series & Organization \\
\hline Sparta & $37^{\circ} 04^{\prime}$ & $22^{\circ} 26^{\prime}$ & 205 & $1956-57,1664-65$ & $\begin{array}{l}\text { Hellenic National } \\
\text { Meteorological Service }\end{array}$ \\
\hline Githio & $36^{\circ} 46^{\prime}$ & $22^{\circ} 34^{\prime}$ & 10 & $1979-80,1991-92$ & $\begin{array}{l}\text { Hellenic National } \\
\text { Meteorological Service }\end{array}$ \\
\hline Arna & $36^{\circ} 53^{\prime}$ & $22^{\circ} 25^{\prime}$ & 760 & $1954-55,1991-92$ & $\begin{array}{l}\text { Hellenic Ministry } \\
\text { for the Environment } \\
\text { Physical Planning } \\
\text { and Public Works }\end{array}$ \\
\hline Karies & $37^{\circ} 18^{\prime}$ & $22^{\circ} 30^{\prime}$ & 880 & $1954-55,1963-64$ & $\begin{array}{l}\text { Hellenic Ministry } \\
\text { for the Environment } \\
\text { Physical Planning } \\
\text { and Public Works }\end{array}$ \\
\hline Vrodamas & $36^{\circ} 58^{\prime}$ & $22^{\circ} 39^{\prime}$ & 150 & $1952-53,1992-93$ & $\begin{array}{l}\text { Hellenic Ministry } \\
\text { for the Environment } \\
\text { Physical Planning } \\
\text { and Public Works }\end{array}$ \\
\hline Petrina & $36^{\circ} 51^{\prime}$ & $22^{\circ} 30^{\prime}$ & 205 & $1954-55,1992-93$ & $\begin{array}{l}\text { Hellenic Ministry } \\
\text { for the Environment } \\
\text { Physical Planning } \\
\text { and Public Works }\end{array}$ \\
\hline Elos & $36^{\circ} 50^{\prime}$ & $22^{\circ} 42^{\prime}$ & 10 & $1972-73,1991-92$ & $\begin{array}{l}\text { Hellenic Ministry } \\
\text { of Agriculture }\end{array}$ \\
\hline Sellasia & $37^{\circ} 10^{\prime}$ & $22^{\circ} 25^{\prime}$ & 560 & $1963-64,1966-67$ & $\begin{array}{l}\text { Hellenic Ministry } \\
\text { of Agriculture }\end{array}$ \\
\hline Bassaras & $37^{\circ} 10^{\prime}$ & $22^{\circ} 30^{\prime}$ & 650 & $1971-72,1992-93$ & $\begin{array}{l}\text { Hellenic Ministry } \\
\text { of Agriculture }\end{array}$ \\
\hline Foinikio & $36^{\circ} 44^{\prime}$ & $22^{\circ} 54^{\prime}$ & 180 & $1978-79,1985-86$ & $\begin{array}{l}\text { Hellenic Ministry } \\
\text { of Agriculture }\end{array}$ \\
\hline Papadianika & $36^{\circ} 43^{\prime}$ & $22^{\circ} 51^{\prime}$ & 60 & $1978-79,1985-86$ & $\begin{array}{l}\text { Hellenic Ministry } \\
\text { of Agriculture }\end{array}$ \\
\hline Kremasti & $36^{\circ} 59^{\prime}$ & $22^{\circ} 52^{\prime}$ & 800 & $1979-80,1985-86$ & $\begin{array}{l}\text { Hellenic Ministry } \\
\text { of Agriculture }\end{array}$ \\
\hline Sikia & $36^{\circ} 46^{\prime}$ & $22^{\circ} 56^{\prime}$ & 160 & $1978-79,1985-86$ & $\begin{array}{l}\text { Hellenic Ministry } \\
\text { of Agriculture }\end{array}$ \\
\hline Metamorfosi & $36^{\circ} 49^{\prime}$ & $22^{\circ} 55^{\prime}$ & 120 & $1978-79,1985-86$ & $\begin{array}{l}\text { Hellenic Ministry } \\
\text { of Agriculture }\end{array}$ \\
\hline Koupia & $36^{\circ} 52^{\prime}$ & $22^{\circ} 54^{\prime}$ & 540 & $1978-79,1985-86$ & $\begin{array}{l}\text { Hellenic Ministry } \\
\text { of Agriculture }\end{array}$ \\
\hline Saint Dimitrios & $36^{\circ} 56^{\prime}$ & $22^{\circ} 49^{\prime}$ & 385 & $1978-79,1992-93$ & $\begin{array}{l}\text { Hellenic Ministry } \\
\text { of Agriculture }\end{array}$ \\
\hline Kastoreio & $37^{\circ} 10^{\prime}$ & $22^{\circ} 18^{\prime}$ & 480 & $1963-64,1966-67$ & $\begin{array}{l}\text { Hellenic Ministry } \\
\text { of Agriculture }\end{array}$ \\
\hline Asopos & $36^{\circ} 44^{\prime}$ & $22^{\circ} 51^{\prime}$ & 55 & $1976-77,1992-93$ & $\begin{array}{l}\text { Hellenic Ministry } \\
\text { of Agriculture }\end{array}$ \\
\hline Molaoi & $36^{\circ} 48^{\prime}$ & $22^{\circ} 51^{\prime}$ & 200 & $1971-72,1992-93$ & $\begin{array}{l}\text { Hellenic Ministry } \\
\text { of Agriculture }\end{array}$ \\
\hline Vamvakou & $37^{\circ} 15^{\prime}$ & $22^{\circ} 34^{\prime}$ & 1000 & $1962-63,1982-83$ & $\begin{array}{l}\text { Hellenic Institute } \\
\text { of Forestal Research }\end{array}$ \\
\hline
\end{tabular}


Table 2. Rainfall Data

\begin{tabular}{|c|c|c|c|c|}
\hline \multicolumn{5}{|c|}{ Meteorological Stations } \\
\hline Year & Month & ARNA & GYTHIO & SPARTA \\
\hline \multicolumn{5}{|c|}{ Rainfall observations (mm) } \\
\hline 1992_1993 & SEP & 7,60 & 14,00 & 7,00 \\
\hline $1992 \quad 1993$ & OCT & 62,80 & 125,49 & 29,30 \\
\hline $1992 \_1993$ & NOV & 122,40 & 230,60 & 99,95 \\
\hline 1992_1993 & DEC & 233,30 & 198,50 & 86,20 \\
\hline $1992 \_1993$ & JAN & 64,60 & 153,04 & 58,25 \\
\hline 1992_1993 & FEB & 249,90 & 98,89 & 52,30 \\
\hline $1992 \_1993$ & MAR & 80,70 & 92,24 & 52,65 \\
\hline 1992_1993 & APR & 6,10 & 70,15 & 47,15 \\
\hline $1992 \_1993$ & MAY & 103,60 & 15,14 & 64,95 \\
\hline $1992 \_1993$ & JUN & 0,00 & 8,55 & 16,23 \\
\hline 1992_1993 & JUL & 28,10 & 13,96 & 15,75 \\
\hline $1992 \_1993$ & AUG & 42,70 & 14,59 & 54,20 \\
\hline 1993_1994 & SEP & 45,80 & 14,20 & 26,13 \\
\hline 1993_1994 & OCT & 123,43 & 127,25 & 82,59 \\
\hline 1993_1994 & NOV & 206,82 & 233,81 & 109,04 \\
\hline 1993_1994 & DEC & 280,67 & 201,25 & 129,25 \\
\hline 1993_1994 & JAN & 253,18 & 155,15 & 119,71 \\
\hline 1993_1994 & FEB & 196,40 & 100,24 & 99,35 \\
\hline $1993 \_1994$ & MAR & 142,27 & 93,50 & 83,53 \\
\hline 1993_1994 & APR & 80,55 & 71,10 & 47,87 \\
\hline 1993_1994 & MAY & 52,36 & 15,35 & 31,17 \\
\hline 1993_1994 & JUN & 20,69 & 8,66 & 14,54 \\
\hline $1993 \_1994$ & JUL & 12,87 & 14,14 & 23,29 \\
\hline 1993_1994 & AUG & 12,15 & 14,78 & 20,53 \\
\hline
\end{tabular}

- Data process and analysis. G.F.I.S. includes different model procedures: Data Processing Model, Hydrologic Model, Geomorphologic Model, Visualization Model, Forecasting Model

- Use of GIS modules and potentials like: overlay, buffering, DTM, DEM, etc.

- Development and assessment of alternatives decision scenarios.

- Variety of forecasting methods

- Forecasting procedures for any time-series and spatial data.

- Data saving in different formats like: .txt, .xls etc

- Printing / plotting reports, charts, and layout maps

G.F.I.S. is a useful tool for data analysis, forecasting and geographic representation. It was developed with MS Visual Basic 6.0 (User Interface), ArcView 3.1 (GIS) and MS Access (DBMS) during the MSc thesis of one of the authors in 2000.
The specific project allocates rainfall and temperature data. For that reason gives the user the opportunity to analyse the case study region and deduce information from the results. With this case study, the user can:

- Take information for the number, characteristics and time-series of each meteorological station

- Hydrological time-series forecast

- Station classification depend on rainfall (annual rainfall or average rainfall)

- Printing / plotting reports, charts, and layout maps for specific region that

The specific project is a very important research because it concerns:

- Forecasting hydrological resources

- Water resource management for environment and sustainable natural resource development (De Vries, 1989).

- Forecasting the effect of the surface flow, inundation, and dryness. 
- Integrated approach of environmental management and development

- The G.F.I.S. is a module of decision supporting in management of hydrological resources

- The effect of management of sustainable natural resource development

- Quality protection of water and soils.

- The Geographic Forecasting Information
System is suitable for all geographic data.

System prospective is:

- The system can be used in many applications and spatial data (social economic data, demographic data, etc) (Martin 1996).

- Many other forecasting methods can be included in the future: econometric methods, neural networks.

\section{REFERENCES}

Andrieu, H., French M.N., Thauvin V. and Krajewski W.F. (1996), Adaptation and application of a quantitative rainfall forecasting model in a mountainous region, Journal of Hydrology, 184, 243-259.

Assimakopoulos, V. (1994), Forecasting Methods, National Technical University of Athens.

Assimakopoulos, V. and Nikolopoulos, K. (2000), The Theta Model: A Decomposition Approach to Forecasting, International Journal of Forecasting, 16, 521-530.

Bindlish, R. and Barros A. (2000) Disaggregation of rainfall for one - way coupling of atmospheric and hydrological models in regions of complex terrain, Global and Planetary Change, 25, 111-132.

De Vries, H.J.M. (1989), Sustainable Development, Croningen, Netherlands.

Maktridakis S., Wheelwright, S. C. and Hyndman R. J. (1998), FORECASTING Methods and Application, 3rd ed., 248-249, 285-286, 335-336.

Martin D. (1996), GEOGRAPHIC INFORMATION SYSTEMS G.I.S. Socio-economic applications, Routledge, London.

Ogilire, K. (1995), Environmental Sustainability in the Ontario Government, York University.

Redclift, M.R. (1993), Sustainable Development: Needs, Values, Rights, Environmental Values, The White Horse Press, Cambridge, U.K. , 2, 3 - 20.

Turner, R. Kerry (ed.) (1993), Sustainable Environmental Economics and Management Principles \& Practice, Belhaven Press. 